\title{
AGE AND TECTONIC SETTING OF THE PALEOCENE GLACIER ISLAND VOLCANIC SEQUENCE OF THE ORCA GROUP IN PRINCE WILLIAM SOUND, ALASKA
}

CAITLIN NOSEWORTHY, Saint Norbert College

Research Advisor: Tim Flood

\section{INTRODUCTION}

Southern Alaska has a long history of subduction, accretion, and coastwise transport of terranes (Coney et al., 1980; Monger et al., 1982; Plafker et al., 1994). The Chugach-Prince William (CPW) terrane is about $2200 \mathrm{~km}$ long and extends through much of southern Alaska (Plafker et al., 1994) (Fig. 1A). The inboard Chugach terrane can be divided into two parts, a mélange and sedimentary units that are Permian to Early Cretaceous in age and a turbidite sequence that is from the Upper Cretaceous (Plafker et al., 1994). In the Prince William Sound area, the outboard Prince William terrane is comprised of Paleocene to Eocene turbidites and associated basaltic rocks of the Orca Group (Davidson and Garver, 2017), and the turbidites of the inboard Chugach terrane are known as the Valdez Group. The turbidites are intruded by the Sanak-Baranof Belt (SBB), a group of 63-47 Ma plutons that are progressively younger to the east. The Border Ranges fault system marks the northern boundary of the CPW terrane, separating the Chugach terrane from the Wrangellia composite terrane and the Contact fault separates the Chugach and Prince William terrane (Fig. 1; Plafker et al., 1994).

There are three ophiolite sequences in the Orca Group: Knight Island (KI), Resurrection Peninsula (RP), and Glacier Island (GI) (Fig. 1B). The KI ophiolite contains a sequence of massive pillow basalts, sheeted dikes, and a minor amount of ultramafic rocks (Tysdal et al, 1977; Nelson and Nelson, 1992; Crowe et al., 1992). The RP ophiolite is a typical ophiolite sequence and has interbedded Paleocene turbidites (Davidson and Garver, 2017). Paleomagnetic data gathered from the RP ophiolite indicated a mean depositional paleolatitude of $54^{\circ} \pm 7^{\circ}$ which implies $13^{\circ} \pm 9^{\circ}$ of poleward displacement (Bol et al., 1992). These data suggest that the RP ophiolite was translated northward to its current position after being formed in the Pacific Northwest, and thus the CPW terrane may have been originally located at $48-49^{\circ}$ north and at 50 Ma was transferred $1100 \mathrm{~km}$ to the north by strike-slip faulting (Cowan, 2003). However, an opposing hypothesis suggests that the terrane has not experienced significant displacement and formed in Alaska due to a now-subducted Resurrection plate (Haeussler et al., 2003).

KI and RP ophiolites have traditionally been assumed to be oceanic crust that was tectonically emplaced into the CPW terrane (Bol et al., 1992; Lytwyn et al., 1997). However, a more recent study suggests a hypothesis that the ophiolites originated in an upper plate setting and formed due to transtension (Davidson and Garver, 2017). Previous workers have used discriminant diagrams to identify the volcanic rocks of KI ophiolite and RP ophiolite as mid-ocean ridge basalts (Lytwyn et al., 1997; Miner, 2012). This project presents new geochemical and geochronological data from the GI ophiolite to determine its age and tectonic setting. The purpose of this study is to compare the data from GI with the data from KI and RP, and the comparison of the geochemical data will allow for a greater understanding of the tectonic setting of southern Alaska.

\section{GEOLOGIC SETTING AND OUTCROP DESCRIPTION}

The Orca Group is composed of turbidites that are 

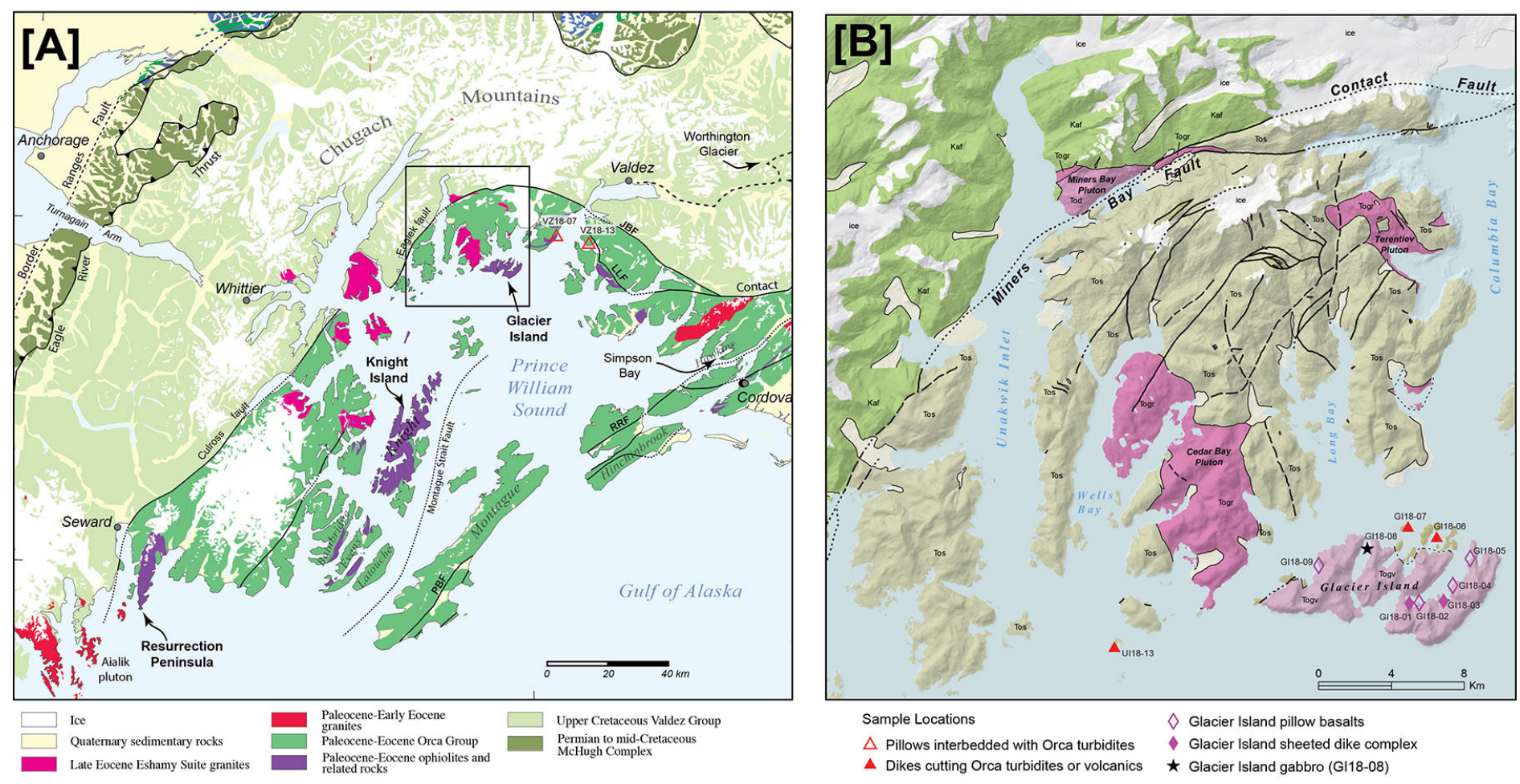

Figure 1: A) Geologic map of the CPW terrane (modified from Bradley et al., 2003). Box shows approximate location of Fig. 1B. B) Geologic Map of Glacier Island and Unakwik Inlet (modified from Wilson et al., 2015).

interbedded with pillow basalt and sheet flows, and is intruded by mafic dikes. The group is Paleocene to Eocene in age and is primarily exposed in Prince William Sound (Wilson and Hults, 2012). The Orca Group is also intruded by the SBB plutons and the Eshamy Suite plutons (Fig. 1). The Orca Group is variably metamorphosed from laumontite to lowergreenschist facies with metamorphic grade increasing to the north and northwest (Wilson and Hults, 2012).

The GI sequence in northern Prince William Sound is a volcanic sequence that has been described as an ophiolite (Nelson et al., 1999, Crowe et al.1992; Bradley et al., 2003). The sequence contains volcaniclastic rocks, pillow basalts with some minor massive basalt flows, and sheeted dikes (Wilson and Hults, 2012). Geologic maps of GI indicate the majority of the island is composed of pillow basalts, but the southern part of the island has a sheeted dike complex (Wilson and Hults, 2012).

The sheeted dikes on Glacier Island range from 10 $\mathrm{cm}$ to $1.5 \mathrm{~m}$ thick (Fig. 2A) and many of the dikes have visible chill margins. One dike, sample GI1807B, intrudes a sandstone unit (Fig. 2C), that allows the age of the dike to be constrained by dating zircons in the sandstone (see below). Some of the dikes and pillows have large $(\sim 4 \mathrm{~mm})$ phenocrysts of plagioclase and all of the dikes have some amount of fracturing. The pillow basalts on Glacier Island have pillows that range in size from $0.25 \mathrm{~m}$ to $1.0 \mathrm{~m}$ in diameter (Fig. 2B) and some of the pillows have large vesicles. Some of the pillow basalts are also brecciated and disorganized likely due to the magma instantly hitting the water.

\section{ANALYTICAL METHODS}

Fourteen samples from Glacier Island and three samples of mafic volcanic rocks interbedded with or intruding turbidites of the Orca Group were collected for geochemical analysis (Fig. 1). The samples were sent to Hamilton College where major element geochemical data were determined using XRF. The glass beads were mounted and polished, and were then sent to Rensselaer Polytechnic Institute for trace element data collected using LA-ICP-MS. Zircons extracted from a sandstone sample from Glacier Island intruded by a mafic dike were analyzed for $\mathrm{U} / \mathrm{Pb}$ at the Laserchron Lab at the University of Arizona. 

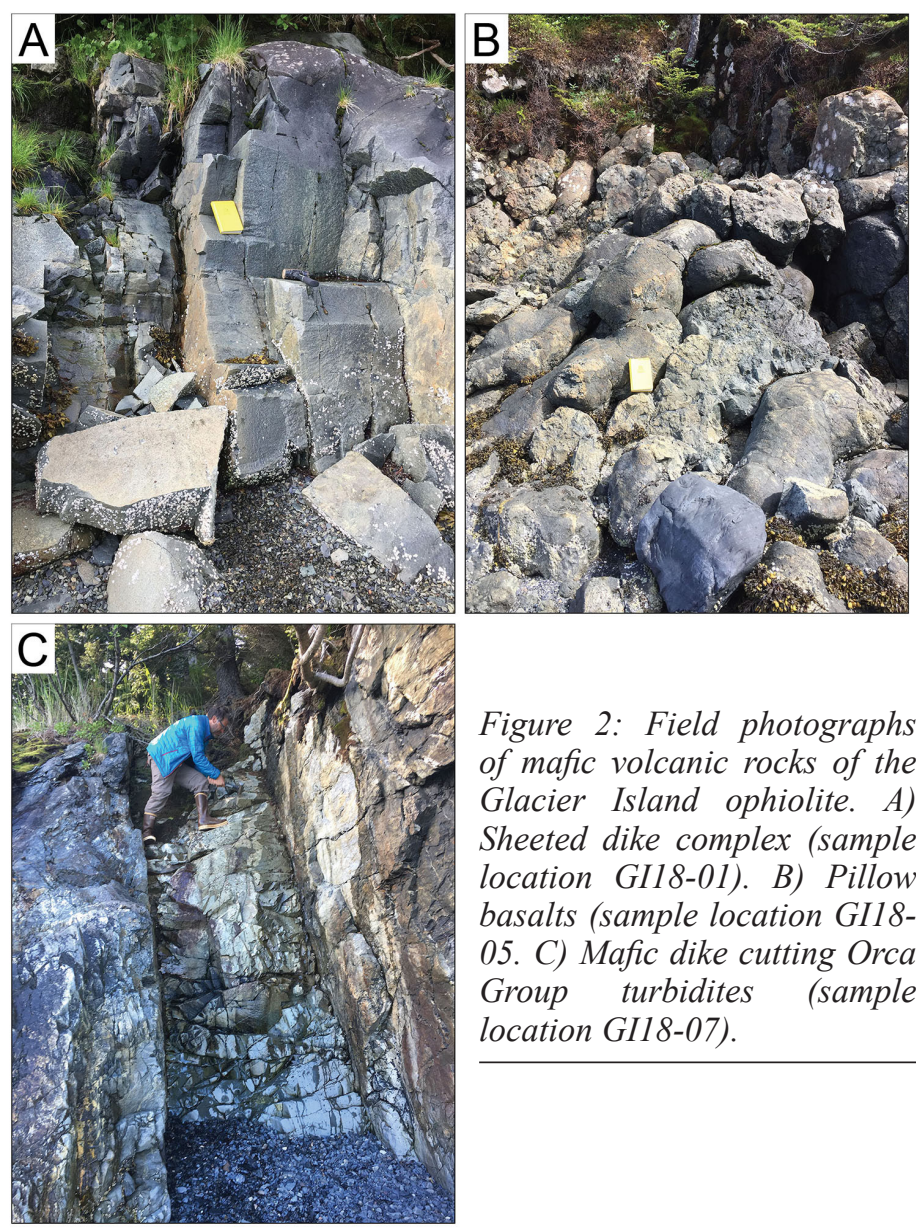

Figure 2: Field photographs of mafic volcanic rocks of the Glacier Island ophiolite. A) Sheeted dike complex (sample location GI18-01). B) Pillow basalts (sample location GI1805. C) Mafic dike cutting Orca Group turbidites (sample location GI18-07).

\section{U/PB RESULTS}

The maximum depositional age (MDA) of the sandstone sample (GI18-07A) is $56.8 \pm 0.6 \mathrm{Ma}$. This number was determined using $\mathrm{U} / \mathrm{Pb}$ analysis of 110 zircon grains and calculating the weighted mean of the three youngest zircon grains (Davidson and Garver, 2017). GI18-07A is cut by a mafic dike assumed to be related to the GI volcanics. The dike intruding the sandstone suggests that volcanism and deposition of the turbidites in the Orca Group occurred together. MDA's of the surrounding Orca Group turbidites have a similar age to GI-07A (Malik et al., this issue; Fisher et al., 2019). The MDA indicates that the dike that intruded the area of the detrital sample must be younger than (or equal to) $56.8 \pm 0.6 \mathrm{Ma}$. These data suggest that the GI, RP, and KI ophiolites are the same age (cf. Davidson and Garver, 2017).

\section{GEOCHEMICAL RESULTS}

All of the mafic volcanic rocks from Glacier Island and northern Prince William Sound from this study plot as basalts and basaltic andesites (Fig. 3A) and are tholeiitic (Fig. 3B). Basalts with a tholeiitic composition are consistent with a mid-ocean ridge origin. On various discrimination diagrams, the GI rocks plot as ocean floor basalts and appear to be most closely aligned with N-MORB (Fig. 4).

Figure 5 shows the rare earth element (REE) abundances from this study and the KI and RP ophiolites. Overall, the majority of the samples from this study have a fairly flat REE pattern indicative of a depleted mantle source, with some samples from Glacier Island showing depletion in the LREE's typical of N-MORB.
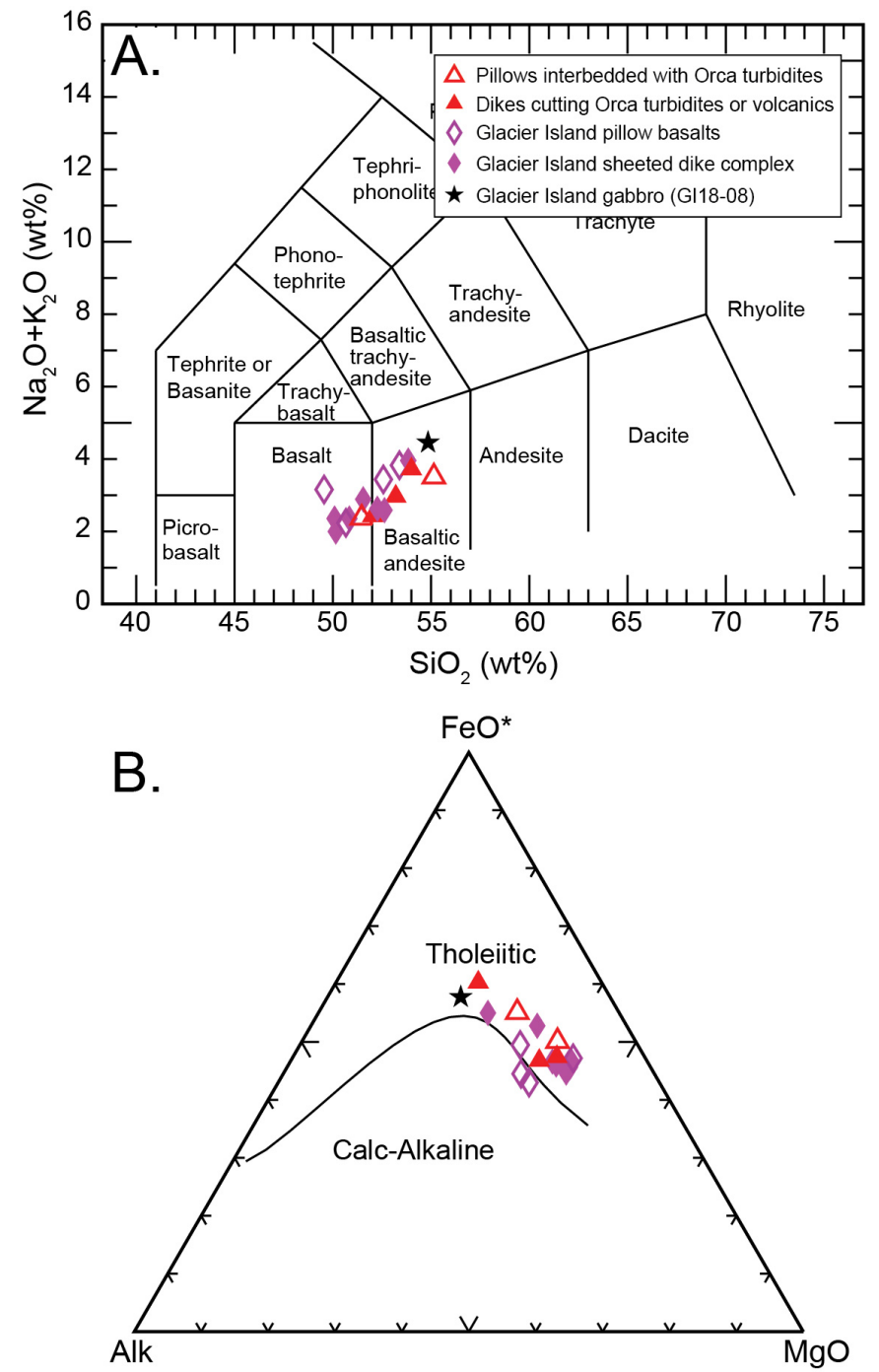

Figure 3: Rock classification diagrams for the Glacier Island ophiolite. A) TAS Diagram (LeBas et al.,1986). B) AFM Diagram (Irvine and Baragar, 1971). Symbols are the same as those shown in Figure 1. 
Thin sections of the four pillow basalt samples from GI are mostly fine-grained and dominated by altered pyroxene and plagioclase. The plagioclase phenocrysts tend to be euhedral and elongated. Three of the thin sections contain amygdules. Overall, significant alteration of the groundmass is noted. This alteration is likely due to the fact that the pillows came in contact with seawater. The alteration seen in thin section is an alternative explanation for the depletion in the LREEs seen in some samples (Fig. 5).

Thin sections for the nine dikes range from finegrained equigranular to coarse-grained porphyritic and are dominated by plagioclase and pyroxenes. The majority of the plagioclase grains are elongated and euhedral. Plagioclase grains exhibit slight to moderate dusty alteration. Pyroxenes are subhedral to anhedral. The pyroxenes range from unaltered to moderately
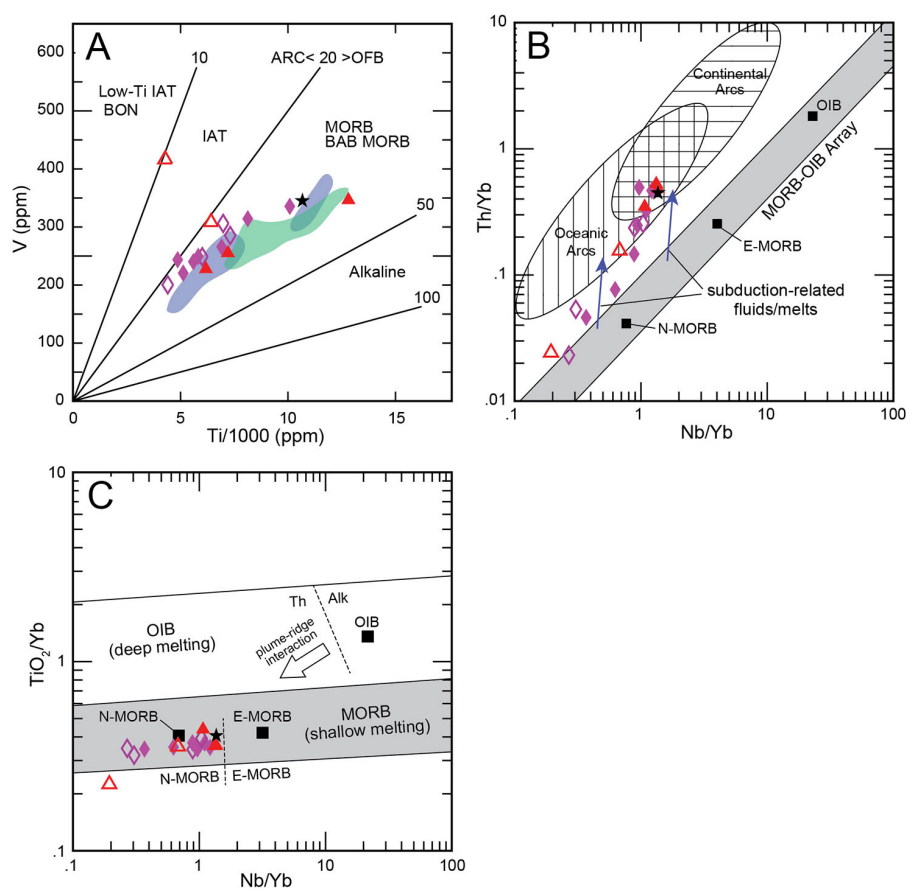

Figure 4: Discrimination diagrams for the Glacier Island ophiolite. Symbols are the same as those shown in Figure 1. A) Ti-V after Shervais (1982). Data from Lytwyn et al. (1997) shown as fields for the Resurrection ophiolite (green) and Knight Island ophiolite (blue). B) Th-Nb proxy from Pearce (2008). N-MORB, E-MORB, and OIB compositions from Sun and McDonough (1989). Blue arrows show the direction MORB compositions change when mixing with melts derived from a mantle wedge infiltrated by subduction-related fluids and melts. C) Ti-Nb proxy from Pearce (2008) that shows the depth/temperature dependence of mantle melts. The data from Glacier Island suggest shallow melting of an N-MORB source.

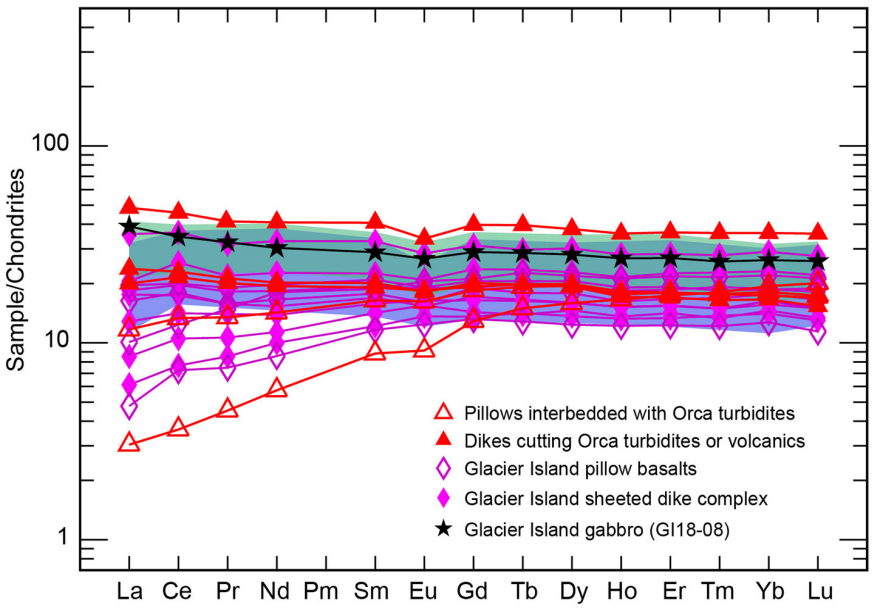

Figure 5: Rare earth element abundances for the Glacier Island, Knight Island, and Resurrection ophiolites normalized to chondrites after Sun and McDonough (1989). Symbols and shaded regions are the same as those shown in Figures $1 \& 4$.

altered. Variable amounts of opaque minerals are present in each of the thin sections.

\section{DISCUSSION}

The detrital zircon results from Glacier Island indicate that the GI ophiolite is $\sim 57 \mathrm{Ma}$ (or younger), and therefore approximately the same age as the RP ophiolite (Bradley, et al., 2003; Davidson and Garver, 2017). The RP ophiolite was directly dated at $57 \pm$ 1 Ma by Nelson et al. (1989) using a plagiogranite assumed to be genetically related to the ophiolite, and Davidson and Garver (2017) dated a sandstone unit interbedded with pillow basalts at the top of the ophiolite that yielded an MDA of $57 \mathrm{Ma}$. The KI ophiolite has not been dated but it is inferred that the ophiolite is the same age as the RP and GI ophiolites because all three are interbedded with the Orca Group turbidites, occur along a strike in the same belt, and are composed of similar rock types (Figs. 4\&5; Bradley, et al., 2003; Davidson and Garver, 2017).

Geochemical data show that the three ophiolites likely originated from the same source. Most of the KI volcanic rock samples are tholeiitic basalts (Lytwyn et al., 1997; Miner, 2012) and the mafic volcanic rocks from GI are also tholeiitic basalts (Fig. 3B). Major and trace element geochemistry from GI are similar to KI and RP basalts and suggest that the rocks originated from a complicated ridge setting (Lytwyn et al., 1997; Miner, 2012) where melts from a spreading 
center (N-MORB) were mixing with melts derived from a mantle wedge that was previously altered by subduction-related fluids or melts (Fig. 4B). REE patterns are also similar between the three ophiolites (Fig. 5); however, the samples in this study were more depleted in LREEs than RP and KI, similar to N-MORB or possibly due to mobilization of the LREE during low-grade metamorphism and/or seafloor alteration.

\section{CONCLUSION}

Based on geochemical data and detrital zircon ages, the Glacier Island, Resurrection Peninsula, and Knight Island ophiolite sequences originated from the same depleted mantle source and within a short period time at $\sim 57 \mathrm{Ma}$. The RP ophiolite has been shown to have translated northward by $13^{\circ} \pm 9^{\circ}$ since it formed (Bol et al., 1992). These data suggest that the RP ophiolite, and therefore the GI and KI ophiolites and associated Orca Group turbidites in Prince Willam Sound were translated northward to their current position after being formed in the Pacific Northwest at $57 \mathrm{Ma}$.

\section{ACKNOWLEDGEMENTS}

This material is based upon work supported by the Keck Geology Consortium and the National Science Foundation under Grant No. 1659322. This project is a part of a larger Keck Consortium project led by Cameron Davidson (Carleton College) and John Garver (Union College). Funding for this project is provided by NSF EAR 1728013 (Garver) and NSF EAR 1727991 (Davidson). XRF data were collected at Hamilton College, LA-ICPMS data were collected at Rensselaer Polytechnic Institute. and $\mathrm{U} / \mathrm{Pb}$ data were collected at the University of Arizona Laserchron Center (NSF-EAR 1649254). Thank you to Tim Flood, Rebecca McKean, and Nelson Ham for being wonderful and supportive advisors throughout the last three years. A big thank you to John Garver and Cameron Davidson for their leadership. Lastly, I want to thank the 2018 Keck Alaska team for all of their hard work and dedication: Will Fisher, Victor Garcia, Nicholas Gross Almonte, Alysala Malik, and Mollie Pope.

\section{REFERENCES}

Bol, A., and Coe, R., 1992, Paleomagnetism of the RP, Alaska: Implications for the Tectonics of Southern Alaska and the Kula-Farallon Ridge, Journal of Geophysical Research, Vol. 97, No. BI2, p.17,21317,232 .

Bradley, D.C., Kusky, T.M., Haeussler, P.J., Goldfarb, R.J., Miller, M.L., Dumoulin, J.A., Nelson, S.W. \& Karl, S.M. 2003, Geologic signature of early Tertiary ridge subduction in Alaska; Geology of a transpressional orogen developed during ridgetrench interaction along the North Pacific margin, Special Paper -Geological Society of America, vol. 371, p. 19-49.

Coney, P. J., Jones, D. L., and Monger, J.W.H., 1980, Cordilleran suspect terranes: Nature, V. 288, p. 329-333.

Cowan, D.S., 2003, Revisiting the Baranof-Leech River hypothesis for early Tertiary coastwise transport of the Chugach-Prince William terrane. Earth and Planetary Science Letters, v. 213, 463- 475.

Crowe, D.E., Nelson, S.W., Brown, P.E., Shanks, W.C., III, and Valley, J.W., 1992, Geology and geochemistry of volcanogenic massive sulfide deposits and related igneous rocks, Prince William Sound, southern Alaska: Economic Geology, v. 87 , p. $1722-1746$.

Davidson, C. and Garver, J.I., 2017, Age and Origin of the Resurrection Ophiolite and Associated Turbidites of the Chugach-Prince William Terrane, Kenai Peninsula, Alaska. The Journal of Geology, 125(6), p.681-700.

Fisher, W.S., Pope, M.D., Malik, A.M., Garver, J.I., and Davidson, C.M., 2019. Zircon facies in the Paleocene-Eocene Orca Group indicate a provenance link to the Chugach terrane, Prince William Sound, Alaska. Geological Society of America Abstracts with Program, Cordilleran Section - 115thAnnual Meeting, Portland Oregon.v. 51, n. 4. Doi: 10.1130/abs/2019CD-329384

Haeussler, P.J., Bradley, D.C., Wells, R.E. and Miller, 
M.L., 2003. Life and death of the Resurrection plate: Evidence for its existence and subduction in the northeastern Pacific in Paleocene-Eocene time. Geological Society of America Bulletin, 115(7), pp.867-880.

Irvine, T.N., and Baragar, W.R.A., 1971, A guide to the chemical classification of the common volcanic rocks. Can. J. Earth Sci., v. 8, p.523-548.

LeBas, M.J., LeMaitre, R.W., Streckeisen, A., and Zanettin, B., 1986. A chemical classification of volcanic rocks based on the total alkali silica diagram. J. Pet. 27:745-750.

Lytwyn, J., Casey, J., Gilbert, S., and Kusky, T., 1997, Arc-like mid-ocean ridge basalt formed seaward of a trench-forearc system just prior to ridge subduction: An example from subaccreted ophiolites in southern Alaska: Journal of Geophysical Research, v. 102, no. B5, p. 10225 10243.

Malik, A.M., Fisher, W.S., Gross Almonte, N., Garver, J.I., Davidson, C.M., 2019. U-Pb dating of detrital zircon from turbidites of the Chugach and Prince William terrane in Prince William Sound, Alaska: Implications of the significance of the Contact fault system as a terrane boundary. Geological Society of America Abstracts with Program, Cordilleran Section - 115th Annual Meeting, Portland Oregon. v. 51, n.4. Doi: 10.1130/abs/2019CD-329396.

Miner, L., 2012, Geochemistry of the KI Ophiolite and Chenega Island Volcanics, Prince William Sound, Alaska. Proceedings of the Twenty-Fifth Annual Keck Research Symposium in Geology, p. 40-47.

Monger, J.W.H., Price, R. A., and Tempelman-Kluit, D. J ., 1982, Tectonic accretion and the Origin of the Two Major Metamorphic and Plutonic Welts in the Canadian Cordillera: Geology, v. 10, p. 70-75.

Nelson, S.W., Miller, M.L., and Dumoulin, J.A., 1989, The Resurrection Peninsula ophiolite, in Nelson, S.W., and Hamilton, T.D., eds., Guide to the geology of the Resurrection Bay-Eastern Kenai Fjords area: Anchorage, Geological Society of Alaska, Guidebook, p. 10-20.
Nelson, S.W., Miller, M.L., Haeussler, P.J., Snee, L.W., Phillips, P.J., and Huber, C., 1999, Preliminary Geologic Map of the Chugach National Forest Special Study Area, Alaska: U.S. Geological Survey and U.S. Forest Service.

Nelson, S.W., and Nelson, M.S., 1992, Geochemistry of ophiolitic rocks from Knight Island, Prince William Sound, Alaska: U.S. Geological Survey Bulletin 2068,

p.130-142.

Pearce, J.A., 2008. Geochemical fingerprinting of oceanic basalts with applications to ophiolite classification and the search for Archean oceanic crust. Lithos 100: 14-48.

Plafker, G., Moore, J.C. \& Winkler, G.R., 1994, Geology of the Southern Alaska margin in The geology of Alaska, eds. G. Plafker \& H.C. Berg, Geological Society of America, Boulder, CO, v. G-1, p. 389-449.

Shervais, J.W., 1982, Ti-V plots and the petrogenesis of modern and ophiolitic lavas, Earth and Planetary Science Letters, 59 (1), p. 101-118.

Sun, S. S. and McDonough, W. F., 1989, Chemical and isotopic systematics of oceanic basalts; implications for mantle composition and processes (in Magmatism in the ocean basins), Geological Society Special Publications, vol. 42 p. 313-345.

Tysdal, R. G.; Case, J. E.; Winkler, G. R.; and Clark, S. H. B. 1977. Sheeted dikes, gabbro, and pillow basalt in flysch of coastal southern Alaska. Geology 5:377-383.

Wilson, F.H. and Hults, C.P., 2012. Geology of the Prince William Sound and Kenai Peninsula region,Alaska. US Geol. Surv. Sci. Invest. Map, 3110, p.37.

Wilson, F.H., Hults, C.P., Mull, C.G, and Karl, S.M, comps., 2015, Geologic map of Alaska: U.S. Geological Survey Scientific Investigations Map 3340, pamphlet 196 p., 2 sheets, scale 1:1,584,000, http://dx.doi.org/10.3133/sim3340. 